\title{
Biodiversity of algae potentially HABS (Harmfull Algae Blooms) in reservoir Mrica, Banjarnegara
}

\author{
${ }^{1}$ Nuraina Andriyani, ${ }^{1}$ Arif Mahdiana, ${ }^{1}$ Rose Dewi, ${ }^{1}$ Yusuf Subagyo, ${ }^{2}$ Asrul sahri siregar, \\ ${ }^{2}$ Teuku Junaidi, ${ }^{2}$ Taufan harisam \\ ${ }^{1}$ Department of Management Waters Resources, Faculty of Fisheries and Marine Resources, \\ University of Jenderal Soedirman \\ ${ }^{2}$ Center of Maritime and Bio science, University of Jenderal Soedirman
}

\begin{abstract}
It has been reported that the waters of the reservoir MricaBanjarnegara were mesotropik-hypereutrophic conditions, potential algal bloom is of Division: Cyanophyta is Microcystis; Chlorophyta is pediastrum; Chrysophyceae is Pyrophyta nitzchia and is Ceratium. Research the types of algae that Potentially HABS (harmfull Algae Blooms) has been Carried out as a continuation of the kinds of research that have the potential of algae blooming. Survey methods was used. Sampling was done by purposive sampling, through 5 (five) sampling sites. Data were Analyzed descriptively. The results Showed that the algae are Potentially HABS of the division Cyanophyta are Microcystis, Anabaena, Oscillatoria and phormidium.
\end{abstract}

\section{INTRODUCTION}

Reservoir Mrica located in District Onion, Banjarnegara district, Central Java Province established on1988. The main objective is the construction of reservoirs for hydropower Mrica with an installed capacity of $180.93 \mathrm{MW}$, in addition reservoirs used for irrigation Mrica DI Banjarcahyana area of 6,550 ha and DI Penaruban area of 900 ha, fish cage system by the local community and tourist attraction. Reservoir catchment area is $957 \mathrm{~km}^{2}$ Mrica. At the reservoir water level $+231 \mathrm{~m}$ asl initial reservoir capacity is 148.287 million $\mathrm{m}^{3}[1]$.

The main river that acts as a medium influx of water and sediment into the reservoir Mrica are Serayu and Merawu River, which flow region is an area of volcanoes (Sumbing, Sindoro and Dieng Mountains). Serayu River is the largest river that goes into Mrica Reservoir. Serayu through an area that largely has undergone further weathered so that they are loose and easily eroded. Serayu watershed morphology has steep cliffs and steep valleys. Vegetation that are often found in the form of crop plants and shrubs, perennials are very rare. Merawu river passing through the area with loose rocks and easily eroded. The rocks on the cliffs of the river is also very prone to erosion because of the soft and easily crushed. Geological conditions in the watershed Merawu unstable so easily happen avalanches. And land-use patterns that there is support in terms of preventing erosion. Land cover in the catchment area (DTA) in the form of forest is less than at the close of land for 
agricultural activities such as plantation, growing vegetables, rice paddy, Polowijo and garden plants. The practice of planting potatoes and cassava less attention to soil and water conservation, thus increasing the rate of erosion. In a hilly area that has a fairly steep slope found many farms with dry land farming practices. Mechanical erosion control have been carried out in the form of a terrace DTA reservoir. In addition to the geological reservoir DTA is a potential area for the occurrence of avalanche danger. From the description above can be concluded DTA Mrica Reservoir is a fertile area with a large enough potential erosion,

Fishing activities by floating net (KJA) have now grown very rapidly and is thought to have passed through the carrying capacity for example is KJA in Cirata. KJA waste crop activities may result in remnants of feed accumulate in the bottom of the reservoir and its decomposition produces nutrients that fertilize the waters often have a negative impact on the marine environment so that water quality continues to decline. One of the main causes of water quality degradation in Cirata is the number of waste from fish farming activities in the KJA. Feed the fish that is not utilized by the fish as much as $27-31 \%$, then of feed consumed by $20 \%$ of the fish will eventually end up being a stool and fell into the water. The rest of the feed and the fish metabolic waste is what is assumed to increase the nutrients in the water such as phosphate and nitrogen [2]. Fish farming activities in the KJA is the largest contributor of domestic waste on Cirata, which is about $80 \%$. The increase in these nutrients can cause bloom toxic algaethat could result in mass death of fish. $[3,4,5,6]$.Toxic algal bloom known as harmfull algae blooms (HABs).

Algae is a plant organism, chlorophyll a role in photosynthesis that produce organic matter and oxygen in waters that are used as a basic link in the feed chain cycle(foodchains). $[7,8]$. However, these algae can be very dangerous when it becomes blooming (growing very quickly or there is a population explosion) as a result of the carrying capacity of water is very high, among others, for example due to the high content of nutrients nitrogen $(\mathrm{N})$ and Phosphorus $(\mathrm{P})[9]$.

Microcystis $s p$ and $s p$ Ceratium, is an example of algae that often bloming in stagnant waters (reservoirs) in Indonesia. One example is the impact of blooming algae bloom of Microcystis sp., Resulting in a natural ecosystem becomes impaired waters since the algae produce toxins microcystin stable in the water and are hepatotoxic $[10,11]$. The toxin inhibits the metabolic processes of plants macrophytes, causing the death of the fish and organisms waters through the chain of feed, also cause liver disease in cattle due to drinking water contaminated with microcystin.

The formulation of the problem of this research is the growth of algae in the waters affected by physical, chemical and biological. Mrica dam water has been polluted by sediment originating from the mountainous Dieng through Serayu and Merawu. Sediment besides containing soil particles also contain nutrients $\mathrm{N}$ and $\mathrm{P}$, so the effect on fertility waters in this case is the growth of algae. Therefore, Blooming algae can occur due to changes in $\mathrm{pH}$, light penetration, temperature, TSS, turbidity, $\mathrm{CO} 2$, ortho phosphate, nitrate resulting from sediments earlier. The purpose of this study was to determine the types of algae that potentially HABs in reservoir Mrica Banjarnegara.

\section{MATERIAL AND METHODS}

The research used descriptive method and the data were analyzed comparatively with Cyanophyta division and table toxic compounds from the Public Health Advisory Guideline 2010. Algae which studied is the nature of planktonic algae, so the sampling and the data analyse together with how to analyze plankton (Table 1).

Table 1. Sampling Station Location 


\begin{tabular}{|c|c|c|c|}
\hline Stations & $\begin{array}{c}\text { Point } \\
\text { Coordinates }\end{array}$ & Research Location & Description Location \\
\hline I & $\begin{array}{l}{ }^{\circ} 23 \text { '25,1S } 07 \text { " } \\
\text { E 10939'59,4 " }\end{array}$ & Merawu & $\begin{array}{l}\text { Rice Fieldriver,moor, } \\
\text { sand mining }\end{array}$ \\
\hline II & $\begin{array}{l}\text { S } 07^{\circ} 22^{\prime} 48,5^{\prime \prime} \\
\text { E } 109^{\prime} 38^{\prime} 23,1 "\end{array}$ & Serayu. & $\begin{array}{l}\text { Rice paddies, fields, } \\
\text { mines pasr }\end{array}$ \\
\hline III & $\begin{array}{l}\text { S } 07^{\circ} 23 \text { ', } 15.2^{\prime} \\
\text { 'E10936'56,7' }\end{array}$ & 'Middlereservoir & dam water Amid \\
\hline IV & $\begin{array}{l}\text { S } 07^{\circ} 22^{\prime}, 48.8^{\prime \prime} \\
\text { E } 109^{\prime} 36^{\prime} 40,9^{\prime \prime}\end{array}$ & $\begin{array}{l}\text { Areas of KJA (Coral } \\
\text { Jambe) }\end{array}$ & KJA Activities \\
\hline V & $\begin{array}{l}\text { S } 0723 \text { ', 29.1' } \\
\text { 'E10936'30,8' }\end{array}$ & 'Outletdam & reservoir At the outet \\
\hline
\end{tabular}

\subsection{Water sampling}

Decisionand preservation of water samples is only done for the parameters that are eksitu (measured in laboratory), which includes TSS, nitrate, orthophosphate, BOD and turbidity by means of a water sample is cooled in the ice box (Table 2). Parameters that are in situ (directly measured in the field) include measurements of temperature, $\mathrm{pH}$, salinity, and carbon dioxide-free.

Table 2. Methods for analysis and standard quality water for phytoplankton (Yuliana, 2012)

\begin{tabular}{|c|c|c|c|c|c|}
\hline No. & Parameter & Unit & Method / Tools & Source & Source \\
\hline 1 & Temperature & ${ }^{0} \mathrm{C}$ & $\begin{array}{l}\text { Expansion } \\
\text { thermometer }\end{array}$ & APHA (2005) & $\begin{array}{c}\text { (Yuliana, } \\
2012)\end{array}$ \\
\hline 3 & Turbidity & NTU & $\begin{array}{l}\text { Nephelometri / } \\
\text { turbidimeter }\end{array}$ & APHA (2005) & $<25$ \\
\hline
\end{tabular}




\begin{tabular}{|c|c|c|c|c|c|}
\hline 4 & TSS & $\begin{array}{c}\mathrm{mg} / \\
\mathrm{L}\end{array}$ & $\begin{array}{l}\text { Grafimetri } \\
\text { Whatman filter } \\
\text { paper No. } 41\end{array}$ & APHA (2005) & - \\
\hline 6 & $\mathrm{CO} 2$ & $\begin{array}{c}\mathrm{mg} / \\
\mathrm{L}\end{array}$ & Erlen Meyer & APHA (2005) & - \\
\hline 7 & $\mathrm{pH}$ & - & $\begin{array}{l}\text { Colorimetric / } \mathrm{pH} \\
\text { paper }\end{array}$ & APHA (2005) & - \\
\hline 8 & BOD & $\mathrm{mg} /$ & Winkler & APHA (2005) & $<25$ \\
\hline 10 & Nitrates & $\mathrm{mg} /$ & $\begin{array}{l}\text { brusin / } \\
\text { spectrophotometer }\end{array}$ & APHA (2005) & $0.9-35$ \\
\hline 11 & orthophosphate & $\mathrm{mg} /$ & $\begin{array}{l}\text { Stannous chloride } \\
\text { / } \\
\text { spectrophotometer }\end{array}$ & APHA (2005) & $\begin{array}{l}0.27- \\
5.51\end{array}$ \\
\hline
\end{tabular}

Monitoring of water quality and plankton found identification conducted in the laboratory of Water Quality Management at Fisheries and Marine Faculty, Laboratory of Soil Science- Faculty of Agriculture Unsoed., And Purbalingga Health Laboratory.

\subsection{Retrieval and Preservation Phytoplankton}

Samples were filtered water as much as $200 \mathrm{~L}$ with a volume of $10 \mathrm{~L}$ plastic bucket and poured into a plankton net no. 25. Water samples were deposited in a plankton net reservoir bottle is transferred into a $30 \mathrm{~mL}$ sample bottle and added with $3 \mathrm{~mL}$ of $40 \%$ formalin so that the water in the bottle normality to $4 \%$ as well as a few drops of Lugol three drops. The samples are stored in the ice box and made observations in the laboratory.

\subsection{Identification and Calculation of abundance of algae}

Phytoplankton samples of $30 \mathrm{~mL}$ were taken observed with a binocular microscope. The samples were homogenized with a pipette and taken as many as three drops, then placed on glass slide. The slides are put in place binocular microscope object. Observations were carried out with repeat 5 times to 30 times the observation point. Phytoplankton had been identified by using the book Davis (1955), Edmonson [2], Sachlan (1982) and the APHA [12]. The calculation of the amount of the abundance of phytoplankton per liter using the formula Microtransect Lackey Drop Counting (APHA, 1989), with the following formula: 


$$
N=n x \frac{A}{B} x \frac{C}{D} x \frac{1}{E}
$$

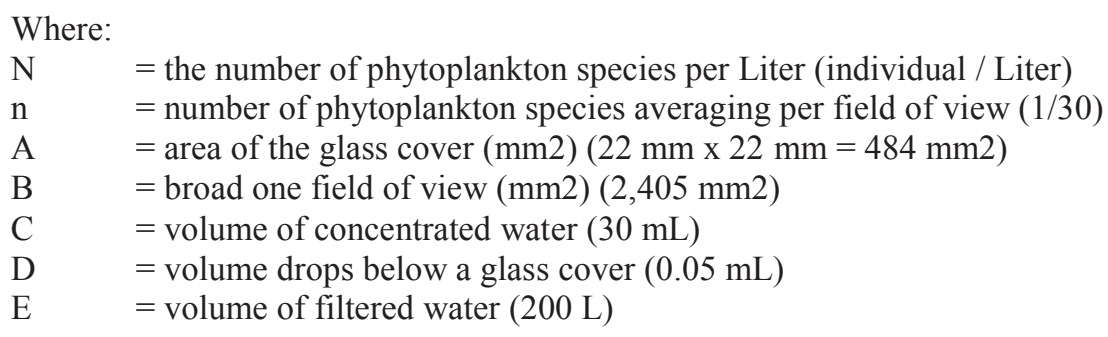

\section{RESULTS AND DISCUSSION}

\subsection{Reservoir water quality Mrica}

Reservoir water quality Mrica compared with the entry in the dam water level mesotropik- Mrica hypereutropik (Table 3). This means that the water conditions are already in the stage of high fertility. High fertility rates will affect the growth of algae, because algae is in dire need of light penetration, phosphorus as well as nitrogen. TSS Serayu and Merawu very high ( $>100$ NTU) indicate that the water contains organic particles and organic carried from upstream or Dieng. Turbidity Serayu and Merawu also high when compared to the central area, KJA and outlets. BOD indicates that the water has been polluted organic waste, as has been widely known that a farm in Dieng as the area above the reservoir Mrica used manure or organic in maintaining soil fertility. However, due to the use of manure is contaminating bottom areas, reservoirs consequently increased nitrate and phosphate nutrients, it will result in the enrichment of the algae $[13,14]$. 
Table 3. Physical parameters -kimia reservoir waters Mrica

\begin{tabular}{|c|c|c|c|c|c|}
\hline PARAMETER & MERAWU & SERAYU & TENGAH & KJA(Kr.Jambe) & OUTLET \\
\hline & I & 1 & 1 & 1 & 1 \\
\hline Jam & 15.01 & 10.25 & 11.22 & 11.53 & 12.57 \\
\hline \multirow[t]{3}{*}{ Lokasi } & S07 $23^{\prime} 25,1^{\prime \prime}$ & S $07^{\circ} 22^{\prime} 48,5^{\prime \prime}$ & S07 $23^{\prime}, 15,2^{\prime \prime}$ & $507^{\circ} 22^{\prime}, 48,8^{\prime \prime}$ & S07 23',29, 1' \\
\hline & E 10939'59,4" & E10938'23,1" & E10936'56,7" & E10936'40,9" & E10936'30,8' \\
\hline & Cerah & Cerah & Cerah & Cerah & Cerah \\
\hline $\mathrm{PH}$ & 7,00 & 7,00 & 7,00 & 7,00 & 7,00 \\
\hline Temperatur (oC) & 28,00 & 20.55 & 28,50 & 28,50 & 28,00 \\
\hline Penet.Cahaya $(\mathrm{cm})$ & 25,50 & 17.5 & 76,25 & 111,25 & 100,00 \\
\hline TSS (ppm) & 101,00 & 127,00 & 57,00 & 33,00 & 16,00 \\
\hline Kekeruhan (NTU) & 39,00 & 50,00 & 5,00 & 2,00 & 4,00 \\
\hline $\mathrm{O} 2$ terlarut (ppm) & 6,15 & 4,80 & 6,10 & 6,40 & 6,60 \\
\hline $\mathrm{CO} 2(\mathrm{ppm})$ & 0,66 & 3,08 & $\mathrm{tt}$ & $\mathrm{tt}$ & $\mathrm{tt}$ \\
\hline BOD (ppm) & 8,33 & 16,67 & 8,89 & 26,67 & 14,87 \\
\hline N Total (ppm) & 1,79 & 4,50 & 1,45 & 0,18 & 1,28 \\
\hline P Total (ppm) & 2,81 & 3,16 & 3,10 & 1,09 & 4,45 \\
\hline Ortho Pospat (ppm) & 0,53 & 0,52 & 0,65 & 0,55 & 0,42 \\
\hline Nitrat (ppm) & 0,08 & 0,07 & 0,10 & 0,31 & 0,39 \\
\hline Klorofil (mg/m3) & 0,18 & 0,18 & 3,92 & 2,67 & 10,28 \\
\hline
\end{tabular}

Increased nitrogen and phosphate, in addition to coming from Dieng also from KJA (Karamba Floating Net). The use of artificial feed or excessive pellet will leave a lot of garbage, litter or feed residue will settle to the bottom waters[15]. The amount of feed residue that settles causing aerobic and anaerobic bacteria are not able to degrade, so that the rest of the food are not degraded perfectly able to form ammonia that are harmful to the organism.

\subsection{The diversity and abundance of algae in the reservoir Mrica}

The diversity and abundance of algae in the reservoir Mrica, the highest of the division Chlorophyta and chrysopyta (Figure 1.). Genus of division Chlorophyta represented pediastrum; Cyanophyta genus of division is represented by Microcystis; genus of divisions represented Chrysophyta nitszchia; and genus of pyrophyta represented by ceratium (Figure $2,3,4,5)$. Genus Microcystis, although the number of individuals less compared to the number of individuals of other genera Microcystis others in fact have a larger size and more because of the size of the colony (Table 4) [16] Algae that live in colonies had greater biomass than the phytoplankton that live solitary (Sachlan, 1982). In quantitative terms Cyanophyta biomass will be greater than the biomass divisio others. So that the state of Microcystis bloom, surface waters can be fully closed. , The Role of the waters of this genus as pemfiksasi nitrogen-free under normal circumstances, but if it happens blooming will remove toxins that will kill the organisms in it, such as toxic by the cyanobacterium Anabaena sp., Microsystis sp., And Nodularia sp.(Table 5) [17,18,7]. 


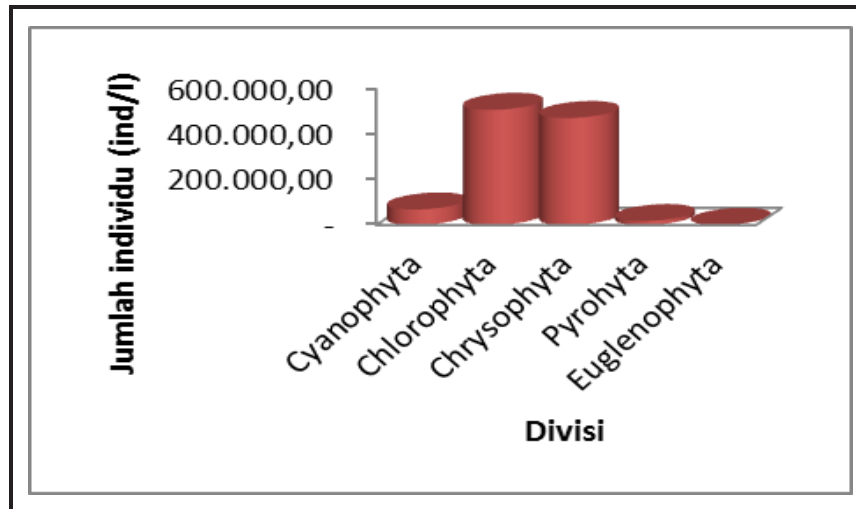

Fig 1. Number of individuals in the genus division of phytoplankton

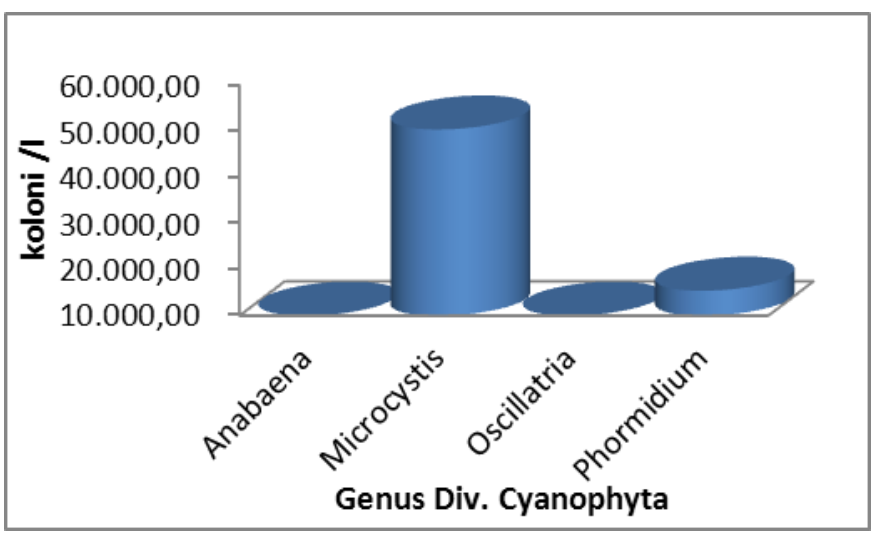

Fig 2. Number of individuals in the genus of div. Cyanophyta

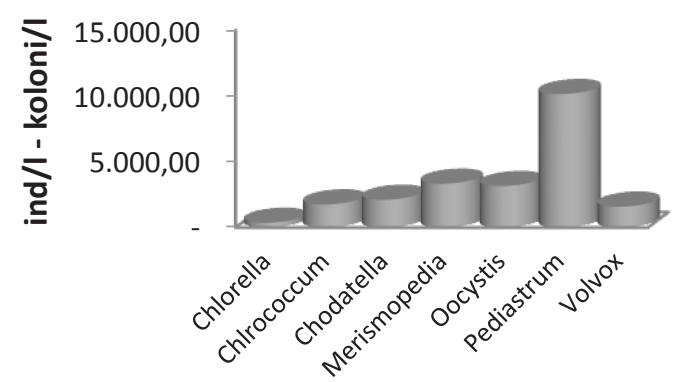

Genus Div.Chlorophyta

Fig 3. Number of individuals in the genus of div. Chlorophyta 


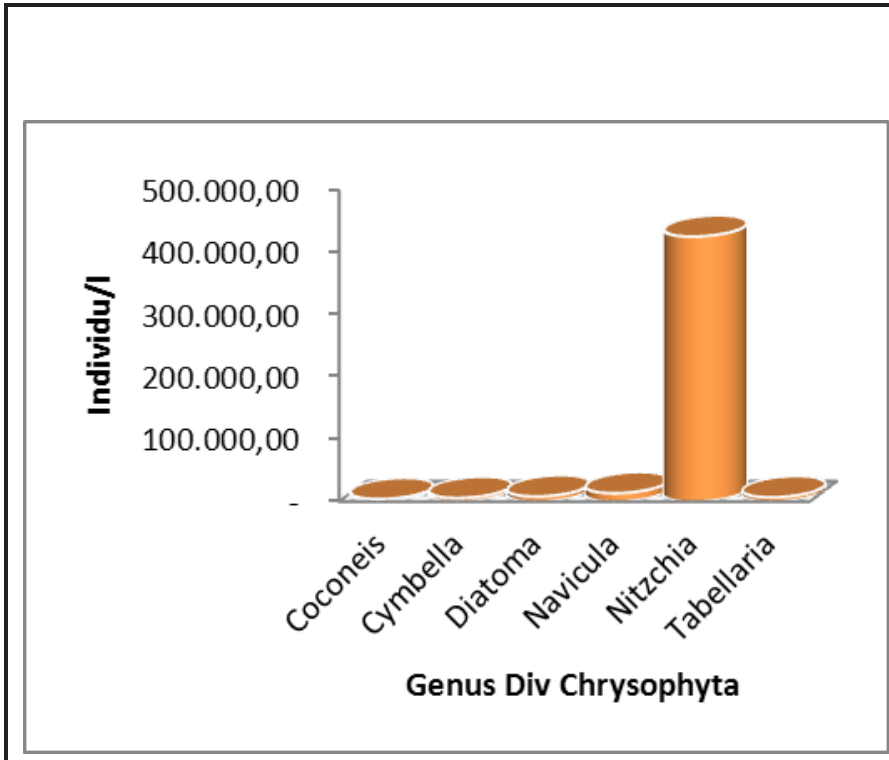

Fig 4. The number of individuals in the genus of div. Chrysophyta

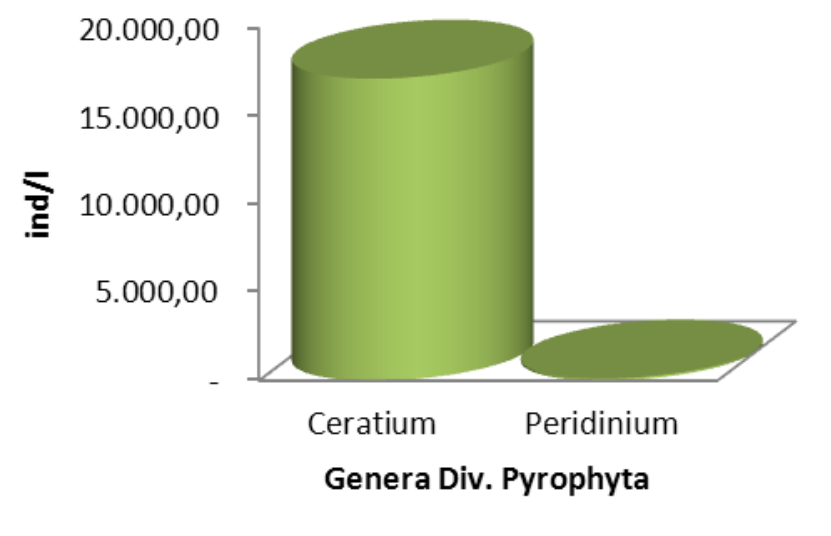

Fig 5. Number of individuals in the genus of div. Pyrophyta

Table 4. Standard rate of eutrophication of waters by the Minister of Environment no. 28 of 2009.

\section{Parameters}

Fertility classificationwaters

\section{oligotrophic Mesotrofik eutrophic}




\begin{tabular}{cccc}
\hline light penetration $(\mathrm{cm})$ & $\geq 400 \geq 250$ & $\geq 1000$ \\
total phosphorus $(\mathrm{mg} / \mathrm{L})$ & $<0.01$ & $<0.03$ & $<0.10$ \\
total nitrogen $(\mathrm{mg} / \mathrm{L})$ & $\leq 0$ & $\leq 0,65,75$ & $\leq 1,9$
\end{tabular}

Table 5. Compound toxin of Division Cyanophyta (Public Health Advisory Guidelines, 2010) Hepatotoxins Neurotoxins

\begin{tabular}{|c|c|c|c|c|}
\hline microcystin & $\begin{array}{l}\text { No } \\
\text { dul } \\
\text { arin }\end{array}$ & $\begin{array}{l}\text { Cyli } \\
\text { ndro } \\
- \\
\text { sper } \\
\text { mop } \\
\text { sin }\end{array}$ & $\begin{array}{l}\text { Ana } \\
\text { toxi } \\
\mathrm{n}-\mathrm{a}\end{array}$ & $\begin{array}{l}\text { sax } \\
\text { ito } \\
\text { xin }\end{array}$ \\
\hline Anabaena & + & + & + & + \\
\hline Anabaenopsis & & & + & \\
\hline $\begin{array}{l}\text { Aphanizomen } \\
\text { on(Except } A \text {. } \\
\text { flos-aquae) }\end{array}$ & + & & + & + \\
\hline Arthrospira & & & + & \\
\hline Cyanobium & & & + & \\
\hline Cylindrospermopsis & & + & & + \\
\hline Gloeotrichia & & & + & \\
\hline Hapalosiphon & & & + & \\
\hline Limnothrix & & & + & \\
\hline
\end{tabular}


Lyngba

Microcystis

Nodularia

Nostoc

Oscillatoria

Phormidium

Planktothrix

Raphidiopsis

Schizothrix

Synechocystis

Umezakia
$+$

$+$

$+$

$+$

$+$

$+$

$+$

$+$

\section{3. $3_{\text {the }}$ types of algae that could potentially lead HABS in waters Mrica}

Algae potentially HABS based on the types of potentially blooming algae were: division Cyanophyta is Microcystis. Microcystis is recommended to be avoided if a water containing up to 40,000 individuals / 1 because it can cause illness to humans (Public Health Program) in addition to Microcystis of Cyanophyta division also found Anabaena, Oscillatoria, and Phormidium. The four genera containing toxins: hepatotoxin and neurotoxins (Table 5). Anabaena containing hepatotoxins (nodularian and cylindrospermin) and neuotoksin (anatoksin and saxitoksin) whereas Microcystis, Oscillatoria and phormidium containing hepatotoxins (cylindrospermin) and neurotoxins (saxitoksin).

\section{CONCLUSIONS}

From the discussion above it can be concluded that the waters of the reservoir Mrica on mesotropik-hipereutropik conditions. Algae are blooming potential of divisions: Cyanophyta is Microcystis; Chlorophyta is pediastrum; Chrysophyta is nitzchia and Pyrophyta is ceratium. Genera which can cause HABs is a division Cyanophyta: Anabaena, Microcystis, Oscillatoria and phormidium. 
Many thanks to DIPA funds PKA (BOPTN) Number: DIPA-023.04.2.189899 / 2013 dated December 5, 2012 Revision to 02 on 1 May 2013 on funds provided sehigga this study can be held. Thanks also we would like to Typhoon Harisam SPi, SPi Ramsie Genda, Fa Rara Yuniarti Anggraeni and Melissa for their assistance and cooperation.

\section{REFERENCE}

1 Andriyani, N; US Siregar; and A. Mahdiana. 2013. The types of algae blooming in the reservoir potential Yag Mrica-Banjarnegara. Paper presented at the National Seminar on "Rural Resource Development and Local Wisdom sustained in LPPM Unsoed Purwokerto. 26 to 27 November 2013.

2 Edmondson, WT 1959. Freshwater Biology. John Willey and Sons Inc. New York.

3 Mizuno, T. 1978. Illustration of The Fresh Water Plankton. Japan: Heikusha Publishing, co. Ltd Osaka.

4 Odum, E.P. 1988. Fundamental of Ecology.Phidelphia: W.B. Sounders Company.

5 Soylu, E.N., and A. Gönülol. 2003. Phytoplankton and seasonal variations of the River Ye ilırmak, Amasya, Turkey. Turkish Journal of Fisheries and Aquatic Sciences 3: $17-24$.

6 Stoddard, A., J.B. Harcum, J.T. Simpson, J.R. Pagenk opf, and R.K. Bastian. 2003, Municipal Wastewater Treatment: Evaluating Improvements in National Water Quality. Published by John Wiley and Sons, Inc.

7 Oren, A. 2011. Naming Cyanophyta / Cyanobacteria-A Bacteriologist's View. Fottea. 11 (1): 9-11.

8 Barange, M and B. Campos. 1991. Model of spesies abundance: a critique of and an alternative to the dynamic model. Marine Ecology Progress Series 69: 293298.

9 Chapman, VJ and DJ Chapman.1973. Algae Freshwater EcologyThe $2^{\text {nd }}$ Edition. The Mac Millan Press, London Hutabarat, S. 2000. Marine Productivity andPlankton.Publisher Agency Dipenogoro University, Semarang.

10 Magurran, A. E. 1988. Ecological Diversity and Its Measurement. Princeton, N.J.: Princeton University Press.

11 Zalocar de Domitrovic, Z.Y., A.S.G. Poi de Neiff, and S.L. Casco. 2007.Abundance and diversity of phytoplankton in the Paraná River (Argentina) $220 \mathrm{~km}$ downstream of the Yacyretá reservoir. Brazil

12 APHA (American Public Health Association). 2005. Standard methods for the examination of water and waste water. $21^{\text {th }}$ edition. Washington DC

13 Onyema, I.C. 2007. The phytoplankton composition, abundance and temporal variation of a polluted estuarine creek in Lagos, Nigeria, Turkish Journal of Fisheries and Aquatic Sciences 7: 89-96.

14 Piirsoo, K., P. Peeter, A. Tuvikene, and V. Malle. 2008. Temporal and spatial patterns of phytoplankton in a temperate lowland river (Emajo gi, Estonia). Journal of Plankton Research 30 (11): 1285-1295.

15 Bledsoe, E., E.J. Phlips, C.E. Jett, and K.A. Donnelly. 2004. The relationships among phytoplankton biomass, nutrient loading and hydrodinamics in an inner shelf estuary. Ophelia 58 (1):20-47.

16 Lacerda, S R., M.L. Koening, S. Neum ann-Leitão, and M.J. Flores-Montes. 2004. Phytoplankton Nyctemeral variation at a tropical river estuary (ItamaracáPernambuco-Brazil). Brazilian Journal of Biology 64 (1): 81-94.

17 Tuvikene, A., K. Piirsoo, and Pall. 2005.Effect of nutrient load on the planktonic biota in the River Narva drainage area. InRusso, R. C. (ed.), 2005. Modelling Nutrient 
Loads and Responses in River and Estuary Systems. Report No. 271. Brussels: Committee on the Challenges at Modern Society, NATO.

18 Ekwu, A.O. and F.D. Sikoki. 2006. Phytoplankton diversity in the cross river estuary of Nigeria, Journal of Applied Sciences \& Environmental Management10 (1): 89-95. 